\title{
社会に対する関心を高めるための授業科目に おける試みとその効果の分析
}

\author{
A Trial in Subjects for Promoting the Interest in Society and an \\ Analysis of the Effect of the Trial
}

\author{
山口 佳 和*1 \\ Yoshikazu YAMAGUCHI
}

\begin{abstract}
In this research, I showed the trial that I conducted in the classes of 3 subjects in Chiba Institute of Technology for promoting the interest in society, and analyzed the short tests of basic knowledge and the questionnaires of the class evaluation and the interest in society. As a result, it is revealed that the trial has positive effect in promoting the basic knowledge necessary for working people and the interest in society. In addition, it is revealed that the trial is effective in strengthening the linkage among the items of the class evaluation and the interest in society.

Keywords : Engineering Education, Interest in Society, Student, Class Evaluation, Questionnaire, Educational Effect

キーワード：工学教育，社会に対する関心，学生，授業評価，アンケート，教育効果
\end{abstract}

\section{1.はじめに}

工業大学または工学系学部の専門教育においては, 専門分野の技術の習得と合わせて, 社会の仕組みを理 解することが重要である．専門分野の技術を習得して も社会の仕組みの理解が十分でないと，その技術を実 際に社会に適用することはできない.JABEE認定基 準の学習・教育目標 ${ }^{1)}$ に扔いても, 社会の理解が技 術者教育の重要な要素とされている.

近年厳しさを増している就職活動においても, 社会 の仕組みの理解が十分でないと，自分が希望する分野 や職種を具体的に考えて的確に表現することはできな い．企業の面接においても，話のやりとりに付いてい くことができない，あるいは的外れな応答を繰り返す という状況に陥る。

千葉工業大学において筆者が担当する学部の授業科 目は，いずれも社会の仕組みの理解に関わりが深いと 認識している．専門科目として専攻分野の知識や手法 を習得させることがまず求められる，加えて，社会の 仕組みの理解を深めるため, 社会に対する関心を高め ることが，担当する授業科目の役割として期待される と考える.

以下では，筆者が2010年度前期に担当した授業科目 において実施した社会に対する関心を高めるための試 みを紹介するとともに，その効果について述べる。

平成 22 年 11 月 2 日受付

※ 1 千葉工業大学社会システム科学部経営情報科学科

\section{2. 研究目的}

筆者は担当する授業科目の中で以下の $(\mathrm{a}) \sim(\mathrm{c})$ の)試 みを実施した。

（a）授業科目に関連した社会人の常識と考えられる基 礎知識を問う基礎知識チェック（補足資料 $1 \sim 3$ ) を第 1 週目の授業で行ってその場で解説するととも に, 第 2 週目以降の授業の関連する箇所で繰り返し 説明する。

（b）授業科目に関連した社会の実例（出来事・事件, 企業・組織，商品・サービス，制度・システムなど） を示す画像（補足資料 $4 \sim 6$ ※本講では著作権のた め画像例の内容を言葉で説明するにとどめる）を， 授業の関連する箇所で提示して説明する。

(c) 授業の説明の中で社会の実例をなるべく多く取り 上げるとともに，学生に意見や感想を求める.

(a)〜 (c) の試みが学生の社会に対する関心の向上に 与える効果を把握することができれば，授業科目の改 善のための基礎的情報を得ることができる．加えて， 社会の仕組みの理解や就職活動にプラスとなる大学教 育のあり方への示唆も得られると考える.

本研究では, 筆者が2010年度前期に担当した (1)ビジ ネスコミュニケーション, (2)企業の法的環境, (3)技術 経営概論の 3 つの授業科目（以下「3 科目」という） を対象とした. (1)は社会システム科学部の経営システ ムコース（JABEEコース）の 2 年生, (2)はJABEEコー ス及びプロジェクトマネジメントコースの 2 年生, (3) はJABEEコース及び経営情報マネジメントコースの 
3 年生向けに開講している ${ }^{2)}$.

3 科目だけでは学生の社会に対する関心の向上に与 える効果は小さいものにとどまるが，それを積み重ね ることでカリキュラム全体として大きな効果とするこ とが可能である。 3 科目の分析結果はそのための基礎 的情報として有用であると考える。

授業第 1 週目（以下「開始時」という）と最終週で ある第15週目（以下「終了時」という）における学生 の変化を調查し分析することにより，(a)〜 (c) の試み が学生の社会に対する関心の向上に与える効果を明ら かにすることを目的とする。

\section{3. 研究方法}

開始時と終了時に以下の基礎知識チェックとアン ケート調査を実施した。

(1)基礎知識チェック

3 科目それぞれについて $\bigcirc \times$ 式の30点満点で採点 し, 基礎知識の学習効果を評価するため開始時と終了 時は同じ内容について出題した。 ただし，内容を理解 しないままの点数上昇を防ぐため, 半数以上の問題は ○×を逆転させた。 なお，問題は社会人であれば常識 と考えられる基礎知識を目指しているが，一部に授業 科目の専門的な問題が含まれる結果となった。

(2)アンケート調査（表 1)

授業科目に対する評価（興味，有用性の認識），社 会に対する関心（将来の仕事への関心，経済・ビジネ

表 1 アンケート調査の質問項目

以下の質問について $5 \sim 6$ 段階に分けた選択肢から回答 させる。

(開始時)

（1）ビジネスコミュニケーション（企業の法的環境, 技 術経営概論）について興味があるか.

(2) ビジネスコミュニケーション（企業の法的環境, 技 術経営概論）の学習は将来の自分にとって役に立つと 思うか.

（3）自分が社会に出たときにどんな仕事をするのかを考 えているか.

(4) 次のメディアの経済・ビジネスのニュース (記事) を見て（読んで）いるか.

(1)テレビ（2)新聞 (3)インターネット

(終了時)

(1) 次の分野には興味を持てたか.

(授業科目の内容を 5 ～6 分野に分けて提示)

(2) 次の分野の学習は将来の自分にとって役に立つと思 うか.

(授業科目の内容を 5 〜 分野に分けて提示)

（3）自分が社会に出たときにどんな仕事をするのかを以 前（開始時）より考えるようになったか.

(4) 次のメディアの経済・ビジネスのニュース (記事) を以前 (開始時) より見る（読む）ようになったか.

(1)テレビ（2)新聞 (3)インターネット
スのニュースを見る頻度）について，5～6段階の選 択肢から回答させた。終了時では，将来の仕事への関 心, 経済・ビジネスのニュースを見る頻度が向上した かを尋ねた。

(1)，(2)を通してサンプルは共通で，ビジネスコミュ ニケーションが53人, 企業の法的環境が 80 人, 技術経 営概論が98人であった。履修学生数はこれらよりも多 い人数であるが, 開始時, 終了時の基礎知識チェック, アンケート調査のすべてに回答していない場合, 真剣 に回答していないと見られる場合は, サンプルから除 外した。 なお， 3 科目でサンプルとなった学生は 2 人, ビジネスコミュニケーションと企業の法的環境の 2 科 目は 13 人, 企業の法的環境と技術経営概論の 2 科目は 1 人であり, いずれもサンプル数が少ないためその他 の学生と合わせて分析することとした。

以上から得られるデータに基づいて, 開始時と終了 時の変化を分析する.

\section{4. 研究結果}

\section{1 開始時と終了時の変化の分析}

一番目に，基礎知識チェックについて見る（図 1 ). 開始時と終了時を比較すると， 3 科目とも少し（1.6 〜2.5点）向上している. 開始時が 3 科目とも10点台 （16.5～19.3点）と低いレベルであり，その割には向 上が少ししか見られず，終了時でも20点前後（18.4〜 21.1点）にとどまっている.

一部に授業科目の専門的な問題が含まれる結果と なったことと， 3 科目の中で企業の法的環境が最も点 数が低いことから学生は法律用語に特になじみがなく 理解しにくいことが原因と考える。授業科目の専門的 な問題, 法律用語であっても社会人として必要な基礎 知識であることから，授業の中でもっと分かりやすく 丁寧な説明を行って点数を向上させる必要がある.

以上から, 基礎知識チェックの点数向上は少しにと どまったものの，3科目とも向上している．授業科目 に関連する範囲内に限定されるものの, 社会人として 必要な基礎知識の向上に $(\mathrm{a}) \sim(\mathrm{c})$ の試みがプラスの効

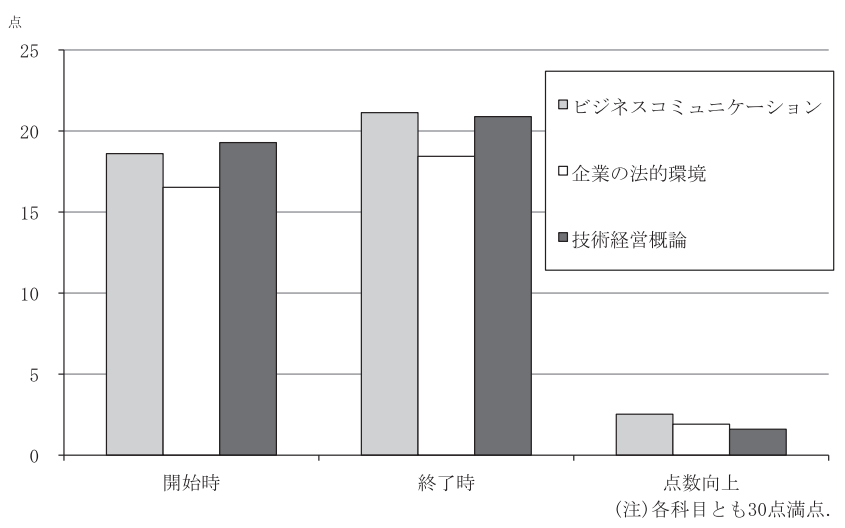

図 1 基礎知識チェックの平均点数と点数向上 


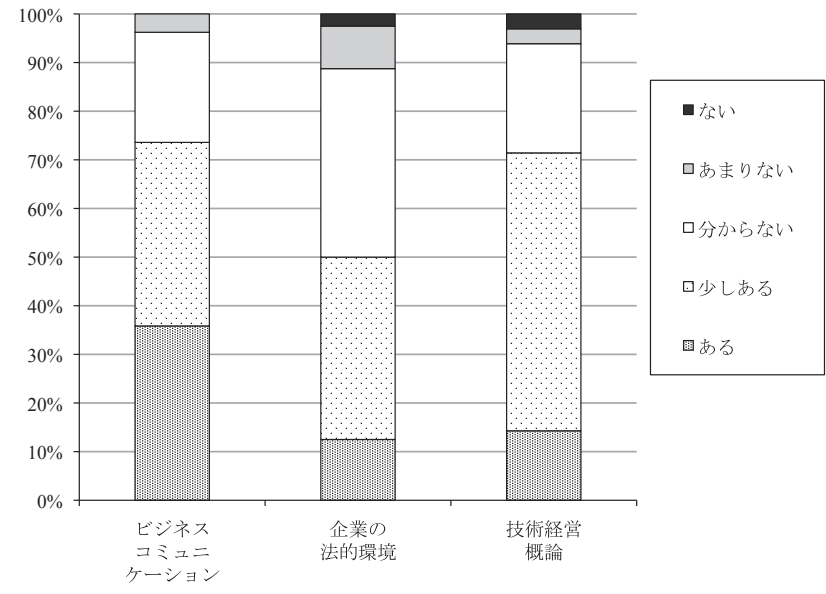

図 2 授業科目への興味（開始時）

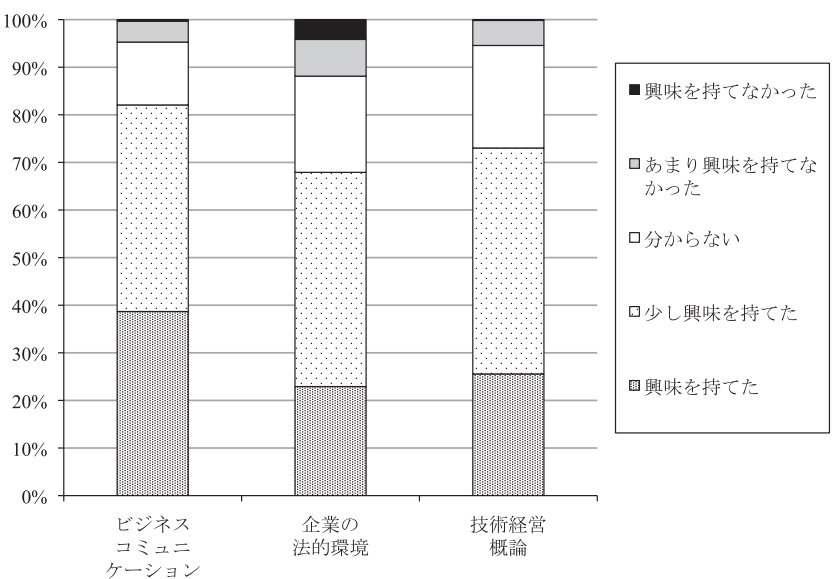

図 3 授業科目への興味（終了時）

果があることが分かった.

二番目に，授業科目に対する評価について見る。授 業科目への興味は, 開始時で「興味がある」または「少 し興味がある」とする回答は, ビジネスコミュニケー ションで $74 \%$, 企業の法的環境で $50 \%$, 技術経営概論 で71\%である（図 2)。これに対して，終了時で「興 味を持てた」または「少し興味を持てた」とする回答

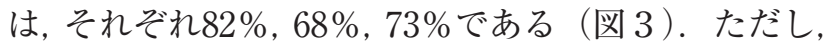
終了時での集計は $5 \sim 6$ 分野の平均值（有用性の認識 も同じ）としている。 3 科目とも開始時よりも終了時 の方が興味が向上している．差が最も大きいのは企業 の法的環境の $18 \%$ 向上である. 開始時には $50 \%$ とあま り興味を持てなかったが，授業を受けて内容がある程 度分かった段階では興味を持てるようになった学生が 多いことを意味している.

授業科目の有用性の認識は，開始時で「役に立 つ」または「少し役に立つ」とする回答は，それぞれ 96\%，76\%，62\%である（図4).これに対して, 終 了時で「役に立つ」または「少し役に立つ」とする回 答は，それぞれ $88 \% ， 77 \% ， 74 \%$ あ゙あ（図 4). ビ ジネスコミュニケーションは開始時の評価が $96 \%$ と非 常に高かったことから，終了時には低下している，企

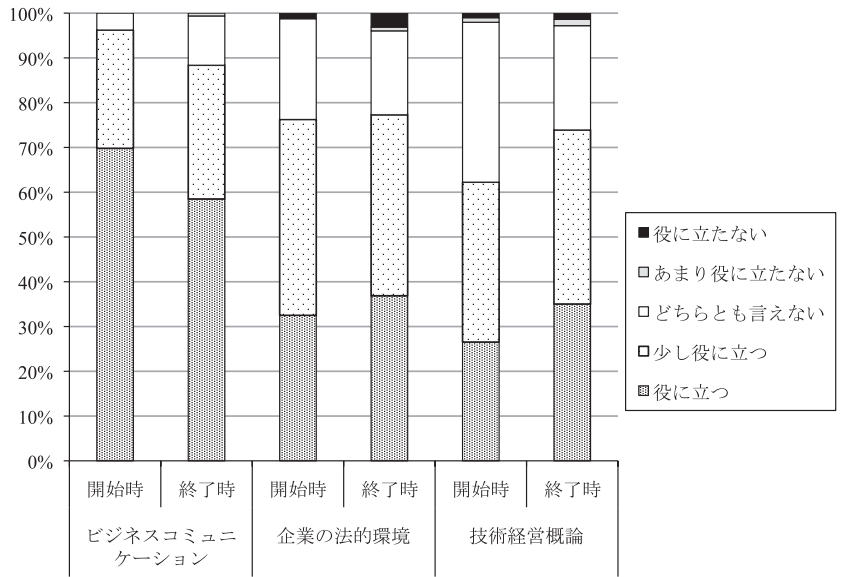

図 4 授業科目の有用性の認識

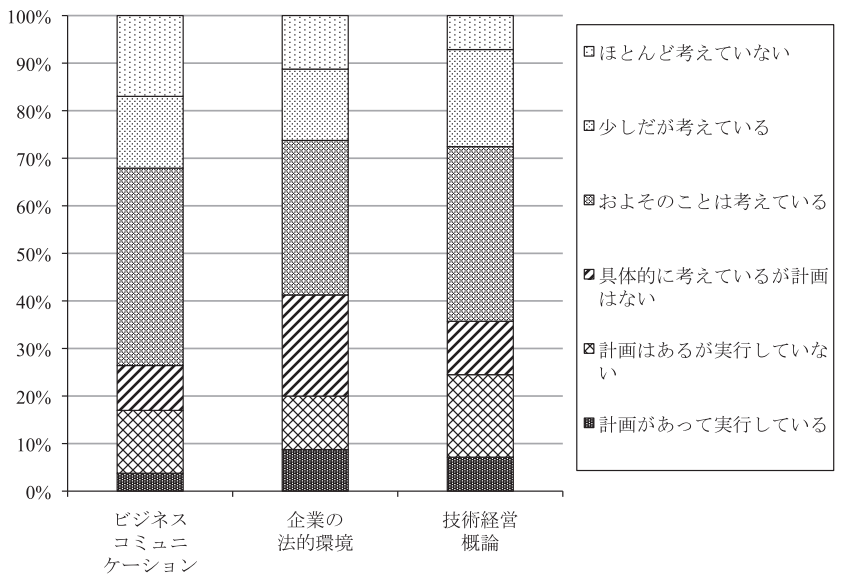

図 5 将来の仕事への関心（開始時）

業の法的環境は開始時には興味は持てないものの有用 性を認識する学生が多い. 3 科目の授業終了時は70 〜 80\%台といずれも高い数值を示している.

以上から， 3 科目とも授業に興味を持たせ，授業の 有用性を認識させることに成功している. 従って, 授 業科目の内容の範囲内に限定されるものの, 社会に対 する関心の向上に $(\mathrm{a}) \sim(\mathrm{c})$ の試みがプラスの効果があ ることが分かった。

三番目に，社会に対する関心について見る。まず， 将来の仕事への関心は, 開始時で「計画があって実行 している」または「計画があるが実行していない」と する回答は, ビジネスコミュニケーションで $17 \%$, 企 業の法的環境で $20 \%$ ，技術経営概論で $24 \%$ あ゙あ（図 5 ).「具体的に考えているが計画はない」以下の回答 は, 将来の仕事への関心が大学生としては弱いと考え るが，それぞれ $83 \% ， 80 \% ， 76 \%$ に達している。これ に対して, 終了時で「以前（開始時を意味する, 以下 同じ）よりょく考える」または「どちらかというと以 前より考える」とする回答は，それぞれ $81 \% ， 71 \%$ ， $69 \%$ である(図 6 )。 3 科目とも大部分の学生の関心 が向上している.

経済・ビジネスのニュースを見る頻度は，開始時で 


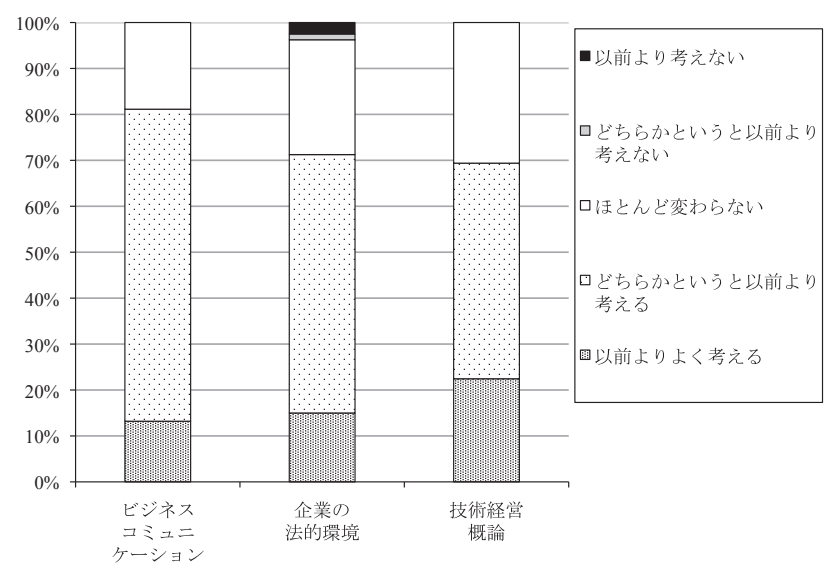

図 6 将来の仕事への関心（終了時）

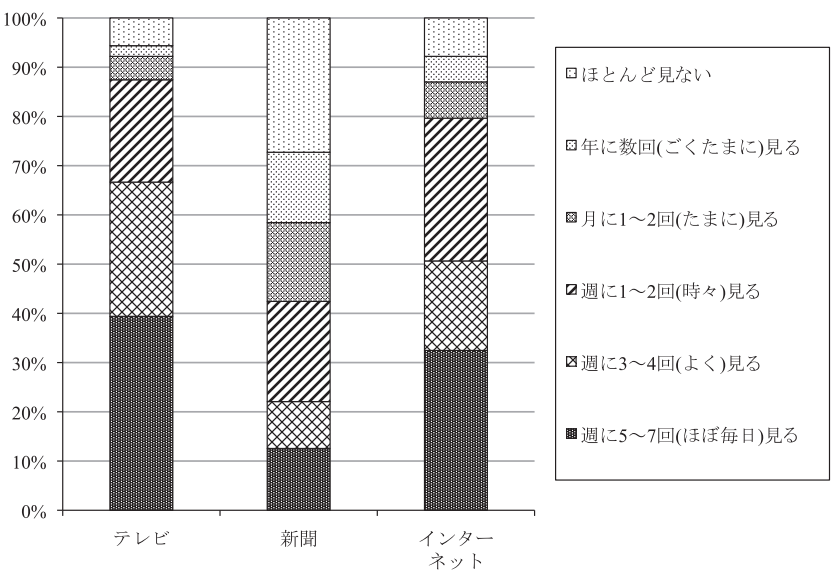

図 7 経済・ビジネスのニュースを見る頻度（開始時）

「ほぼ毎日見る」または「よく見る」とする回答は，

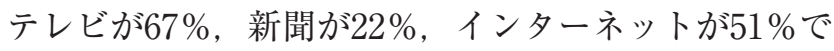
ある (図 7 )。「時々見る」以下の回答は, 経済・ビジ ネスのニュースを見る頻度が大学生としては少ないと 考える. 3つのうちのどれかを見ればよいことになる が, 新聞の $22 \%$ は低いレベルである. 10代, 20 代の若 年層を中心に新聞を読まなくなっておりインターネッ 卜の利用が多くなっているとの報告 ${ }^{3)}$ があるが，そ のことがここにも表れている。これに対して, 終了時 で「以前よりよく見る」または「どちらかというと 以前より見る」とする回答は，それぞれ $47 \% ， 37 \%$ ， $52 \%$ あ゙あ（図 8 )。 3 つのメディアとも頻度が向上 している.なお，この傾向は 3 科目に分けても概ね同 じである.

これらの調查では, 終了時では以前より向上したか を尋ねており開始時とは質問が違っているため, 学生 の意識を変えるという意味に限定された向上であると 考える.

以上から， 3 科目とも将来の仕事への関心と経済・ ビジネスのニュースを見る頻度が向上している．従っ て，学生の意識を変えるという意味に限定されるもの の，社会に対する関心の向上に (a)〜 (c) の試みがプラ

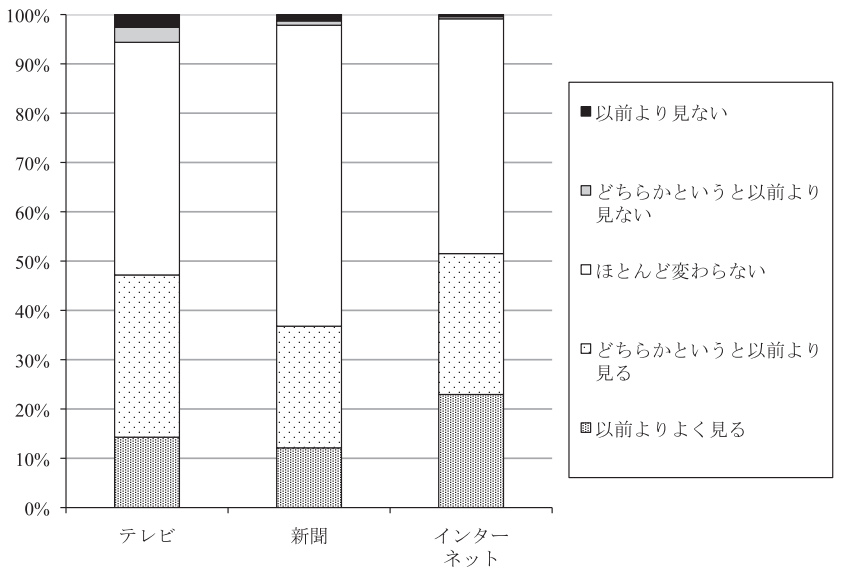

図 8 経済・ビジネスのニュースを見る頻度（終了時）

スの効果があることが分かった.

\section{2 項目間の相関分析}

アンケート調査, 基礎知識チェックの項目間の相関 を見る。まず, 開始時（表 2 ）では, 授業科目への興 味と授業科目の有用性の認識の間に中程度または弱い 相関がある（ $0 \leqq|R|<0.2$ は相関がほとんどない, 0.2 $\leqq|\mathrm{R}|<0.4$ は弱い, $0.4 \leqq|\mathrm{R}|<0.7$ は中程度, $0.7 \leqq$ $|R| \leqq 1.0$ は強い)。このことを除けば，授業科目への 興味, 授業科目の有用性の認識, 将来の仕事への関心, 経済・ビジネスのニュースを見る頻度の間には，それ ぞれ $1 \sim 2$ 科目で弱い相関がある, または 3 科目とも 相関がほとんどない.

基礎知識チェック点数はどの項目とも相関（ $5 \%$ 有 意）がないため, 表 2 には含めていない. 基礎知識は 長期間の蓄積として身に付くものであり, 現時点の学 生の授業科目に対する評価や社会に対する関心とは結 び付きが弱いためと考える.

これに対して, 終了時（表 3 ）では, 授業科目への 興味と授業科目の有用性の認識の間に強いまたは中程

表 2 開始時のアンケート調査項目の相関

\begin{tabular}{|c|c|c|c|}
\hline & $\begin{array}{l}\text { 授業科目の } \\
\text { 有用性の認 } \\
\text { 識 }(2)\end{array}$ & $\begin{array}{l}\text { 将来の仕事 } \\
\text { への関心 }(3)\end{array}$ & $\begin{array}{l}\text { 経済・ビジネ } \\
\text { スのニュー } \\
\text { スを見る頻 } \\
\text { 度 }(4)\end{array}$ \\
\hline \multirow{3}{*}{$\begin{array}{l}\text { 授 業 科 目 } \\
\text { の興味 (1) }\end{array}$} & $0.444^{* * *}$ & $0.330^{*}$ & $0.316^{*}$ \\
\hline & $0.417^{* * *}$ & -0.026 & 0.171 \\
\hline & $0.307^{* * *}$ & 0.076 & $0.232^{*}$ \\
\hline \multirow{3}{*}{$\begin{array}{l}\text { 授業科目の } \\
\text { 有用性の認 } \\
\text { 識 }(2)\end{array}$} & & $0.274^{*}$ & 0.136 \\
\hline & & 0.015 & 0.142 \\
\hline & & 0.075 & 0.117 \\
\hline \multirow{3}{*}{$\begin{array}{l}\text { 将来の仕 事 } \\
\text { への関心 }(3)\end{array}$} & & & 0.139 \\
\hline & & & 0.049 \\
\hline & & & $0.236^{*}$ \\
\hline
\end{tabular}

（注）上段はビジネスコミュニケーション，中段は企業の法的 環境，下段は技術経営概論.

（1）（4) は表 1 中の質問項目番号.

${ }^{*} \mathrm{p}<5 \%,{ }^{* *} \mathrm{p}<1 \%, \quad{ }^{* * *} \mathrm{p}<0.5 \%$ または $\mathrm{p} \ll 0.5 \%$. 
表 3 終了時のアンケート調査項目, 基礎知識チェックの相関

\begin{tabular}{|c|c|c|c|c|}
\hline & $\begin{array}{l}\text { 授業科目の有用性の認 } \\
\text { 識 }(2)\end{array}$ & $\begin{array}{l}\text { 将来の仕事への関心の } \\
\text { 向上 }(3)\end{array}$ & $\begin{array}{l}\text { 経済・ビジネスのニュー } \\
\text { スを見る頻度の向上 }(4)\end{array}$ & 基礎知識チェック点数 \\
\hline $\begin{array}{l}\text { 授業科目への興味 } \\
\text { (1) }\end{array}$ & $\begin{array}{l}0.685^{* * *} \\
0.746^{* * *} \\
0.595^{* * *}\end{array}$ & $\begin{array}{l}0.474^{* * *} \\
0.391^{* * *} \\
0.354^{* * *}\end{array}$ & $\begin{array}{l}0.387^{* * *} \\
0.404^{* * *} \\
0.296^{* * *} \\
\end{array}$ & $\begin{array}{r}-0.172 \\
0.057 \\
0.056\end{array}$ \\
\hline $\begin{array}{l}\text { 授業科目の有用性 } \\
\text { の認識 }(2)\end{array}$ & & $\begin{array}{l}0.245 \\
0.369^{* * *} \\
0.176\end{array}$ & $\begin{array}{l}0.447^{* * *} \\
0.305^{* *} \\
0.194\end{array}$ & $\begin{array}{l}-0.130 \\
-0.028 \\
-0.033\end{array}$ \\
\hline $\begin{array}{l}\text { 将来の仕事への関 } \\
\text { 心の向上 (3) }\end{array}$ & & & $\begin{array}{l}0.489^{* * *} \\
0.486^{* * *} \\
0.426^{* * *}\end{array}$ & $\begin{array}{l}-0.189 \\
-0.009 \\
-0.089\end{array}$ \\
\hline $\begin{array}{l}\text { 経済・ビジネスの } \\
\text { ニュースを見る頻 } \\
\text { 度の向上 (4) }\end{array}$ & & & & $\begin{array}{l}-0.239 \\
-0.321^{* * *} \\
-0.221^{*}\end{array}$ \\
\hline
\end{tabular}

（注）上段はビジネスコミュニケーション, 中段は企業の法的環境, 下段は技術経営概論.

(1)〜 (4) は表 1 中の質問項目番号.

${ }^{*} \mathrm{p}<5 \%,{ }^{* *} \mathrm{p}<1 \%,{ }^{* * *} \mathrm{p}<0.5 \%$ まは $\mathrm{p} \ll 0.5 \%$.

度の相関があり， 3 科目とも相関が強まっている。こ のこと以外にも，授業科目への興味，授業科目の有用 性の認識, 将来の仕事への関心の向上, 経済・ビジネ スのニュースを見る頻度の向上の間には，相関する科 目 (5\%有意) が延べ 5 科目から 12 科目に増加し，そ のうち 6 科目で弱いまたはほとんどないから中程度へ 相関が強まっている.

授業を受けることにより，授業科目への興味，授業 科目の有用性の認識, 将来の仕事への関心の向上, 経 済・ビジネスのニュースを見る頻度の向上という項 目間でリンクするようになったと考える。基礎知識 チェック点数はほとんどの項目とは相関がないが, 経 済・ビジネスのニュース見る頻度の向上との間でマイ ナスの弱い相関がある。点数が低い学生ほどニュース を見る頻度が向上したことになり，学生の危機感が高 まったことを意味している。

これらの調査では，終了時では以前より向上したか を尋ねており開始時とは質問が違っているため，学生 の意識を変えるという意味に限定された相関の強まり であると考える。

以上から， 3 科目とも学生の意識が変化しており, (a)〜 (c)の試みが授業科目の評価，社会に対する関心 の項目間のリンケージを強める効果があることが分 かった. 基礎知識チェックについては, 点数の低い学 生の危機感を高めて経済・ビジネスのニュースを見る 頻度を向上させる効果があることが分かった。

\section{5.まとめ}

(a)〜 (c) の試みが，社会人として必要な基礎知識と 社会に対する関心の向上に，プラスの効果があること が分かった. さらに, 学生の授業科目の評価, 社会に 対する関心の項目間のリンケージを強める効果がある ことが分かった。

これらの効果は, 開始時と終了時の間の $3 \sim 4$ 力月 間と, 4 年間の大学教育から見ると比較的短い期間に 生じた違いである。試みの有無によらない 3 科目自体 の効果あるいは大学教育全体の効果があることは否定 できないものの，(a)〜 (c)の試みによる効果は大きい と考える.

さらに，3科目だけでは学生の社会に対する関心の 向上は小さなものにとどまると考える. 他の授業科目 との連携を強めつつ, カリキュラム全体として社会に 対する関心を向上させることが必要である。これと関 連して, 就職活動を有利に進められる能力を育成する ことも, 大学にとって重要である.

\section{参 考 文 献}

1 ）日本技術者教育認定機構：日本技術者教育認定基 準 (2010年度〜), 2010

2 ) 千葉工業大学: 社会システム科学部学生便覧 (2008 年度, 2009年度), 2008, 2009

3 ) NHK放送文化研究所：2005年国民生活時間調査 報告書, 2005 


\section{補 足 資 料}

1. ビジネスコミュニケーション基礎知識チェック （10.04.09実施）の問題（○か×を付ける）

(1) business(ビジネス)の語源はbusy（忙しい)である.

(2) 夏場に涼しいファッションで省エネを達成しようと いうクールビズの「ビズ」は，ビジュアル(visual) の ことでファッションを意味している.

（3）日本国憲法第21条には「通信の秘密は，これを侵し てはならない」と規定されている.

(4) 通信に使われる電波が進む速度は，光が進む速度と 同じである。

(5)言語や感情表現ができないレベルの動物においても, コミュニケーションが存在しているとされている.

（6）社会人基礎力とは社会人が仕事をしていく上で共通 して必要な能力のことで, 文部科学省が提唱している.

（7）日本語は漢字，漢語を多用するなど中国語と共通な 点が多いことから，言語の系統としては中国語に近い とされている.

(8)ものの形をかたどって描かれた文字である象形文字 には古代エジプトのヒエログリフなどがあるが, 現在 では限られた地域または民族でしか使われていない.

(9) 活版印刷技術はルネサンスの 3 大発明の 1 つとされ ている.

（10）コンピュー夕は 2 進法を使っているため，10進法の 0.1を正確に表すことができず桁数に応じた誤差が生じ る.

(11)インターネットは米国において軍事用のシステムを 目的として開発されたものが基になっている.

(12) 地方自治体の関連企業などを第 3 七クターと呼んで いるが，第 1 セクターや第 2 セクターは存在せずそう いう言い方は使われていない。

（13）企業が中小企業であるかどうかは，当該企業の市場 に㧍ける競争力とは関係なく法律に定義が規定されて いる.

（14）ビジネスに怙ける「ほうれんそう」とは「報告, 連携, 相談」を略したものである.

（15）マナーとは一般には文化や宗教によらない世界共通 のものを意味している.

（16）日本では茶碗，汁椀などの食器をテーブルに置いた まま食べることはマナー違反とされるが，外国では逆 に食器を持ち上げることがマナー違反とされる場合が 多い.

（17）有給休暇は労働者の権利であるが，年間に許された 日数内であればいつでも取ることができるというわけ ではない.

(18) 自分のことをよく知っている人に電子メールを送る 場合は，件名を省略しても問題はないとされている.

(19)ビジネスでいう企画書は社内に対してだけでなく, 社外に対しても作成され使用されることがある.

(20) 実印とは企業や個人のフルネームが入った一定以上 の大きさの印鑑のことを意味しており，重要な契約や 書類に用いられる。

（21）「扯啓」で開始した手紙は「敬具」で終了する。
（22）「ご自愛ください」とは「ご自分に限らず関係者と 広く愛しみあっていただいて仲良くやっていきましょ う」という意味である.

（23）「御中」は公式な地位にいる相手に公式な手紙を出 す場合に付ける敬称で, 「習志野株式会社営業一課芝 園一郎様御中」のように用いる.

(24) パワーポイント (Power Point) はマイクロソフト (Microsoft) 社が供給する最も一般的なプレゼンテー ションソフトウェアである.

(25) プロジェクターを使ってスライドショー形式でプレ ゼンテーションを行う場合は, 映し出される文章を正 確に読み上げるようにすると理解が梁まって効果的で ある。

(26) 異文化との遭遇の典型例とされる19世紀に浦賀沖に 現れた黒船は，英国が派遣した海軍の艦隊である。

(27) Could we have your sign on this contract?(この契 約書に署名していただけますか.）は正しい英語であ る.

(28)I look forward to seeing you in the near future. (近 いうちにあなたに昖会いできることを楽しみにしてい ます.）は正しい英語である.

(29) 英語はヨーロッパ言語の中ではそれほど歴史の長い 言語ではなく, 英語以外のヨーロッパ言語から多くの 単語を導入している.

（30）日本語だけでなく英語でも丁寧な表現は可能ではあ るが，英語では現在は限られた場合を除いて使用され ることはない

2. 企業の法的環境基礎知識チェック（10.04.09実施） の問題（○か×を付ける）

(1) 憲法は国会の 3 分の 2 以上の議決により改正するこ とができる。

(2)法律は内閣の決定により制定することができる。

(3) 毎年度の国の予算を決定するためには, 国会の議決 が必要である。

（4）地方自治体が制定する条例で法律よりも厳しい基準 の規制を定めた場合は，法律の基準を上回る分の規制 については強制力がない.

(5) 法律違反に対する罰則の規定が法律にない場合は, 裁判所は法律違反に対して罰則を与える判決を下すこ とができない.

（6）殺人を犯しても時効を過ぎてしまうと，刑罰を科す ことができない.

（7）「国際法」という名前の法律は存在していない.

(8) 企業の不祥事が相次ぎ企業の倫理や社会的責任が問 題となったのは，戦後になって発生した現象である。

(9)法律の規定には通しで条文番号が付けられているが, 法律改正に伴って欠番が生じることがある.

（10）「会社法」という名前の法律は存在していない.

（11）株主総会は一部の例外の場合を除いて株主の中から 選ばれた株主代表で構成される。

（12）株式が上場された株式会社であれば，一時的に空席 である場合を除いて代表取締役社長が必ず存在する。 
（13）手続きを完了して一旦成立した株式会社であって も，随時解散することが可能である。

（14）「契約法」という名前の法律は存在していない.

(15) 契約は法律上は契約書が作成されないと有効ではな く，裁判になった場合には争うことができない．

(16) 何日の何時に何人分の席を確保するというレストラ ンの予約は, 注文する料理が決まっていなくても法律 上は契約である。

（17）新会員を権誘した会員に対して払込金額を超える配 当を与えるいわゆるネズミ講は, 現在では法律で禁止 されている.

(18)独占禁止法は日本では戦後に制定された法律であ る.

（19）公正な競争により市場シェアを獲得し独占企業と なった場合であっても, 独占禁止法を適用することが できる。

(20) 本や音楽CDについては製造業者が決めた価格でし か消費者に販売することができないという取り決めを 行うことが可能である.

(21)独占禁止法の運用は一部を除いて経済産業省が担当 している.

(22) 製造物責任法 (PL法) は世界に先駆けて日本で制定さ れた法律である。

(23) 森永ヒ素ミルク事件は戦前に発生した製品による大 規模被害の例である.

（24）欠陥住宅であっても不動産に対しては，製造物責任 法(PL法)は適用されない.

(25) 販売を目的としないことが明確な個人が改造した自 動車であれば，一部の例外を除いて型式認可を取得す る必要はない.

(26) 仕事の成績が著しく悪いと判断できる社員が複数人 いる場合, 経営者はその中から気に入らない社員を随 時解雇することができる。

(27) 内定の段階では労働契約は成立していないので，内 定取り消しについては企業の道義的な責任はあっても 法的な責任を問うことはできない.

(28) 日本では公害問題は戦前から存在していた社会問題 である。

(29) 二酸化炭素 $\left(\mathrm{CO}_{2}\right)$ は太陽から地球に到達する光をさ えぎる性質が強いため，これにより温室効果をもたら している.

（30）アスベストは古くからある天然由来の化学物質で, 耐久性，耐熱性，電気絶縁性に優れているが，発癌性 が問題である。

3. 技術経営概論基礎知識チェック（10.04.14実施） の問題（○か×を付ける）

(1) 産業革命は18世紀後半のアメリカで始まり，それに 刺激される形でヨーロッパ各国でも続いて産業革命が 起こった。

(2)アダム・スミス (Adam Smith) は人々の利己心の追求 は見えざる手によって調整されるため経済が発展し国 は豊かになるとして自由競争・自由放任を主張した。
（3）マルクス (Marx)は資本主義の欠点を補うためには民 間に任せるのではなく政府の経済介入が必要だとして 修正資本主義を主張した。

(4) 第 2 次世界大戦の原因の 1 つにブロック経済を形成 する国々と遅れてきた国々との衝突があったとの反省 から，戦後は自由貿易のための国際的な仕組みが作ら れた。

（5）ベルリンの壁崩壊は超大国アメリカの影響力低下と ヨーロッパのアメリカからの自立を象徵する事件で あったとされている。

(6) 証券取引所は資本主義経済を支える株式会社の株の 取引を行う場であるが，現在では中国やロシアでも設 置されている.

(7) 需要供給曲線は自由競争によって需要と供給が価格 と取引数量が鈞り合ったところに落ち着くという市場 メカニズムを表現している。

(8) 円高になると輸入に頼っている原材料の価格が上昇 するため，そうした高い原材料を使って製品を製造， 販売する企業の経営が苦しくなるのが一般的である.

(9)為替レートが 1 ドル100円から110円になったという ことは，円安になったということを意味している.

(10)バブル経済は経済の実態を超えて景気が過熱するこ とであり，その崩壊はある時点で瞬時に起こることが 知られている.

(11)イノベーション (innovation) は日本語の技術革新と は意味が異なっている。

(12) 戦争時に戦争のために開発された新技術は軍事用で あるので，民生用の技術として産業化されることは稀 である。

(13) 戦術 (tactics) は一般には戦略 (strategy)よりも大局 的な計画であるとされている.

（14）孫子は中国の春秋時代に著された兵法書であり，現 代では軍人だけでなく多くの企業経営者にも読まれて いる.

(15) 自然科学分野のノーベル賞は数学, 物理学, 化学, 生理学・医学の 4 部門から選定され授与される.

(16) 人間の細胞のうちのほとんどは限られた回数しか細 胞分裂することができない.

(17) 半導体集積回路 (IC) を高密度化すると信号処理速度 は上昇するものの，一般には熱が発生しやすくなりそ の対策が課題である.

(18) 現在の日本の民間の研究開発投資額は政府の研究開 発投資額とほぼ等しい規模であることが知られてい る.

(19)独創的な研究成果を創出するためには, 知的刺激が 多い環境下で研究者の自由な発想を促進することが一 般には必要である。

(20)家庭やオフィスに供給されている電力は電圧やプラ グの形が国によって異なるが，周波数も国によって異 なっている.

(21) ウィンドウズ (Windows) は現在ではアメリカ政府だ けでなく日本政府からも公認された国際的に通用する スタンダードとなっている. 
(22)SI単位系では時間は秒，長さはメートル，質量はキ ログラムを用いる。

(23) 様々な単位の表記に用いられるメガ (mega) は 1 万 倍, 逆にマイクロ (micro) は 1 万分の 1 を意味してい る.

（24）リスク (risk) とは危険なことを意味し，企業経営に おいてはリスクがほぼゼロになるまでは新事業や新プ ロジェクトの立ち上げを行わないのが一般的である.

(25) ナレッジ (knowledge) とは科学技術の先端的な知識 だけでなく, 工場労働者が経験によって獲得した技能 も含まれる。

(26)ITの発達によって世界中から大量の情報を瞬時に 集めることができ，情報の真偽も正確に分かるように なったとされている.

(27) 大学は非営利の機関であるため, 大学が特許を出願 して権利化することはあっても，その特許権の民間企 業への有償の譲渡やライセンシングは一部の例外を除 いて禁止されている.

(28)ベンチャー企業は民間企業や民間人が起業する場合 だけでなく，大学の研究者が起業する場合もある。

(29) 政府の政策を実施する各府省の長である大臣は国会 議員でなければならないと規定されている.

(30)科学技術政策とは専ら文部科学省が担当している政 策であり，文部科学省以外の府省ではほとんど行われ てはいない.

4. ビジネスコミュニケーションの提示画像の例

\begin{tabular}{|c|c|}
\hline $\begin{array}{l}\text { 《各地域・各国で使用され } \\
\text { ている言語・文字の分布を } \\
\text { 世界地図上に示した図》 }\end{array}$ & $\begin{array}{l}\text { 《ビジネスプレゼンテー } \\
\text { ション（大会場でのセミ } \\
\text { ナー, 会議室での説明, 個 } \\
\text { 別の商談）の様子を表す画 } \\
\text { 像》 }\end{array}$ \\
\hline $\begin{array}{l}\text { 《企業で作成・使用されて } \\
\text { いるビジネス文書 (企画書, } \\
\text { 事務文書, 社交文書, 契約 } \\
\text { 書, 名刺) の画像》 }\end{array}$ & $\begin{array}{l}\text { 《歴史的な異文化交流の事 } \\
\text { 例 (シルクロード, ヨーロッ } \\
\text { パ人による大航海, 黒船来 } \\
\text { 襲, 人種のるつぼ) を示す } \\
\text { 画像》 }\end{array}$ \\
\hline
\end{tabular}

5. 企業の法的環境の提示画像の例

\begin{tabular}{|c|c|}
\hline $\begin{array}{l}\text { 《企業不祥事の事例（公害 } \\
\text { 問題, 薬害問題, リコール } \\
\text { 隠し, 食品偽装) を示す画 } \\
\text { 像》 }\end{array}$ & $\begin{array}{l}\text { 《身近な契約の例（ソフト } \\
\text { ウェア使用許諾, 運送約款, } \\
\text { レストラン予約）を示す画 } \\
\text { 像》 }\end{array}$ \\
\hline $\begin{array}{l}\text { 《株式会社の機関・仕組み } \\
\text { （株主総会, 取締役会, 証 } \\
\text { 券取引所）の様子を表す画 } \\
\text { 像》 }\end{array}$ & $\begin{array}{l}\text { 《独占·寡占企業の例 }(\text { ボー } \\
\text { イング・エアバス, カーギ } \\
\text { ル, デビアス, コカコーラ・ } \\
\text { ペプシコーラ } \text { を示す画像》 }\end{array}$ \\
\hline
\end{tabular}

\section{6. 技術経営概論の提示画像の例}

\begin{tabular}{|c|c|}
\hline $\begin{array}{l}\text { 《歴史上の } 4 \text { 次の産業革命 } \\
\text { における技術革新の事例を } \\
\text { 示す画像》 }\end{array}$ & $\begin{array}{l}\text { 《身近な標準化の例（乾電 } \\
\text { 池, 電力・コンセント, 計 } \\
\text { 量標準, シャンプーのきざ } \\
\text { み) を示す画像》 }\end{array}$ \\
\hline $\begin{array}{l}\text { 《身近なイノベーションの } \\
\text { 例 (パソコン・インターネッ } \\
\text { ト・携帯電話, 宅配便, コ } \\
\text { ンビニエンスストア, セル } \\
\text { フのコーヒーショップ) を } \\
\text { 示す画像》 }\end{array}$ & $\begin{array}{l}\text { 《様々なマーケットの例 } \\
\text { (食品市場, 商品取引所, } \\
\text { 外国為替市場) を示す画像》 }\end{array}$ \\
\hline
\end{tabular}

著者紹介

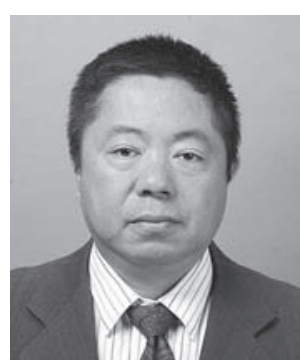

山口 佳和

1979年東京大学工学部電気工学科卒業 2004年東北大学大学院工学研究科技術社 会システム専攻修了, 博士（工学） 1979年通商産業省（現経済産業省）入省, この間, 防衛庁 (現防衛省), 科学技術庁 (現 文部科学省), 内閣府 (総合科学技術会議 事務局), 広島大学などに出向

2007年より千葉工業大学社会システム科 学部経営情報科学科教授, 現在に至る 